\title{
Review \\ Microplastics and Potentially Toxic Elements: Potential Human Exposure Pathways through Agricultural Lands and Policy Based Countermeasures
}

\author{
Avanthi Deshani Igalavithana ${ }^{1}$, Mahagama Gedara Y. L. Mahagamage ${ }^{2}\left(\mathbb{D}\right.$, Pradeep Gajanayake ${ }^{3}$, \\ Amila Abeynayaka ${ }^{4,5, *(\mathbb{D}}$, Premakumara Jagath Dickella Gamaralalage ${ }^{4}$, Masataka Ohgaki ${ }^{6}$, Miyuki Takenaka ${ }^{6}$, \\ Takayuki Fukai ${ }^{6}$ (D) and Norihiro Itsubo ${ }^{5}$
}

check for updates

Citation: Igalavithana, A.D.; Mahagamage, M.G.Y.L.; Gajanayake, P.; Abeynayaka, A.; Gamaralalage, P.J.D.; Ohgaki, M.; Takenaka, M.; Fukai, T.; Itsubo, N. Microplastics and Potentially Toxic Elements: Potential Human Exposure Pathways through Agricultural Lands and Policy Based Countermeasures. Microplastics 2022, 1, 102-120. https://doi.org/10.3390/ microplastics1010007

Academic Editor: Nicolas Kalogerakis

Received: 17 December 2021

Accepted: 19 January 2022

Published: 21 January 2022

Publisher's Note: MDPI stays neutral with regard to jurisdictional claims in published maps and institutional affiliations.

Copyright: (C) 2022 by the authors. Licensee MDPI, Basel, Switzerland. This article is an open access article distributed under the terms and conditions of the Creative Commons Attribution (CC BY) license (https:// creativecommons.org/licenses/by/ $4.0 /)$.
1 Department of Soil Science, Faculty of Agriculture, University of Peradeniya, Peradeniya 20400, Sri Lanka; adigalavithana@agri.pdn.ac.lk

2 Centre for Environmental Studies and Sustainable Development, The Open University of Sri Lanka, Nugegoda 10250, Sri Lanka; mgyma@ou.ac.lk

3 Department of Biosystems Technology, Faculty of Technology, University of Sri Jayewardenepura, Pitipana, Homagama 10200, Sri Lanka; pradeepgajanayake@sjp.ac.lk

4 IGES Centre Collaborating with UNEP on Environmental Technologies (CCET), Institute for Global Environmental Strategies (IGES), 2108-11 Kamiyamaguchi, Hayama 240-0115, Kanagawa, Japan; premakumara@iges.or.jp

5 Graduate School of Environmental and Information Studies, Tokyo City University, Tsuzuki Ward, Yokohama 224-0015, Kanagawa, Japan; itsubo-n@tcu.ac.jp

6 Hitachi High-Tech Science Corporation, 2-15-5 Shintomi, Chuo City, Tokyo 104-0041, Japan; masataka.ogaki.fu@hitachi-hightech.com (M.O.); miyuki.takenaka.zp@hitachi-hightech.com (M.T.); takayuki.fukai.yd@hitachi-hightech.com (T.F.)

* Correspondence: abeynayaka@iges.or.jp

\begin{abstract}
Microplastics (MPs) have been identified as an emerging soil pollutant and a global environmental concern. Scientists have recently paid attention to the contamination of soil by MPs as their detrimental impacts on soil systems are largely unknown. MPs are considered to be vectors for other soil contaminants, such as potentially toxic elements (PTEs) and organic contaminants. PTEs are persistent contaminants and are often released into soils in large quantities. MPs adsorb PTEs, mainly via electrostatic attraction and surface complexation, and increase their mobility in soils. These complexes can be easily absorbed by plants; hence, the accumulation of PTEs in plants can be enhanced in both microplastic and PTE contaminated soils. Furthermore, there is a high risk of food chains contamination by PTEs due to crops grown in both microplastic and PTE-contaminated soils. Consequently, countermeasures including policy- and governance-based approaches that target circular economy as well as reduce, reuse, recycle (3R) applications are being discussed around the world to minimize the environmental contamination of MPs.
\end{abstract}

Keywords: microplastics; toxins; plastic-related toxins; plant absorption; contamination path-way; policy and governance

\section{Introduction}

Plastic production and utilization have increased tremendously during the past couple of decades and reached a remarkable level with the COVID-19 pandemic [1]. In the COVID-19 pandemic 1.6 million tons/day of plastic waste has been generated globally, mainly due to the increased production of disposable personal protective equipment; this means there was an annual generation of $75 \mathrm{~kg}$ of plastic waste per capita [2,3]. These anthropogenic synthetic materials have accumulated in soils due to several reasons, such as improper waste disposal, the application of sewage sludge as fertilizers, soil mulching, and precipitation [4-7]. It has been identified that more than $95 \%$ of the microplastics (MPs) in domestic wastewater are transferred into sewage sludge at wastewater treatment 
plants [8]. The application of this contaminated sewage sludge to agricultural lands adds a substantial amount of MPs to those lands [9]. Furthermore, plastic-coated fertilizers are another direct intestinal application of MPs into agricultural lands that has occurred over the last two decades, and now report accumulations and consequent effects [10]. Mulching plastic sheets annually add a large amount of MPs to agricultural soils, which showed a significant impact on soil bulk density and water infiltration. Furthermore, those MPs tend to accumulate in soil while increasing the absorption by plants and alter biological functions [11,12]. Moreover, recent studies have very clearly shown that there is a higher accumulation of MPs in soils than in aquatic environments, and a potential entering of MPs in the terrestrial food web $[13,14]$. However, soil pollution by MPs has received insufficient attention compared to marine ecosystems [13].

Microplastics can cause adverse impacts on the biodiversity and quality of soils due to their high resistance to biodegradation [15]. MPs tend to be directly ingested by soil macroorganisms and accumulate in body tissues, unfavorably affecting their survival. Furthermore, the accumulation of MPs in soils might negatively impact beneficial microbial populations in soils [16].

In addition, MPs in soils act as adsorbents for both organic and inorganic contaminants [17-19]. Potentially toxic elements (PTEs) are important inorganic soil contaminants that cause negative impacts on soil and food quality [20,21]. PTEs are easily absorbed by plants; hence, the production of foods in contaminated agricultural soils threatens the quality of said foods [20]. PTEs in the soils can be adsorbed onto the surface of MPs, which are simply absorbed by plants. Moreover, PTEs adsorbed onto MPs have shown high mobility in soils due to their low weight and size; hence, surrounding soils can be contaminated with both MPs and PTEs [22,23]. Weathered MPs in the environment have shown a higher capacity to adsorb PTEs than their pristine forms [24,25].

The studies conducted on MPs and their potential to be vectors for PTEs in soils have received minor attention. Hence, this review has the focus of discussing the (1) mechanisms of the adsorption of PTEs onto MPs and their transportation in soils, (2) environmental factors affecting the adsorption of PTEs onto MPs, (3) plant adsorption of PTE-adsorbed MPs and their toxicity, and (4) research gaps, future prospects, and possible countermeasures, focusing in particular on policy and governance.

\section{Adsorption of Potentially Toxic Elements onto MPs}

MPs serve as vectors for both potentially toxic elements (PTEs) (i.e., $\mathrm{Fe}, \mathrm{Mn}, \mathrm{Al}, \mathrm{Pb}$, $\mathrm{Cu}, \mathrm{Ag}$, and $\mathrm{Zn}$ ) and hydrophobic organic contaminants (i.e., persistent organic pollutants (POPs) such as polychlorinated biphenyls (PCBs), organochlorine pesticides (OCPs), and polyaromatic hydrocarbons (PAHs)) [26]. The adsorption of PTEs onto MPs and their possible transportation mechanism via MPs are discussed in this section.

\subsection{Adsorption Mechanisms of Potentially Toxic Elements on MPs}

It has been reported that the adsorption of PTEs onto MPs occurred at high concentrations [26]. Holmes et al. [27] reported PTEs adsorbed on polyethylene resin pellets collected from the beaches in Southwest England, and Mohsen et al. [28] observed adsorbed PTEs (i.e., $\mathrm{As}, \mathrm{Cd}, \mathrm{Cr}, \mathrm{Cu}, \mathrm{Mn}, \mathrm{Ni}, \mathrm{Pb}$, and $\mathrm{Zn}$ ) on isolated MPs from sea cucumber culture ponds in China. In a study conducted to evaluate the PTEs adsorption on MPs of chlorinated polyethylene (CPE), Polyvinyl chloride (PVC), and two types of polyethylene plastic particles of LPE and HPE showed the high adsorption capacities of $\mathrm{Pb}^{2+}, \mathrm{Cu}^{2+}$, and $\mathrm{Cd}^{2+}$ on all MPs [19]. The $\mathrm{Pb}^{2+}$ showed strong adsorption compared to the others due to strong electrostatic interaction. Moreover, the considered PTEs showed the highest sorption affinity to chlorinated polyethylene due to it high polarity and negativity created with the presence of chlorine [29]. The chemical structure and electronegativity of MPs are responsible for the adsorption of PTEs. Differently, the adsorption process seems to not be affected by the crystallinity [19]. Gasperi et al. [30] investigated airborne fibrous MPs and transport pollutants through MPs, further mentioning that airborne fibrous MPs may carry 
pollutants adsorbed from the surrounding environment due to their hydrophobic surface. According to the study by Holmes et al. [27] metal adsorption may have occurred through the interactions between bivalent cations (e.g., $\mathrm{Cu}^{2+}, \mathrm{Cd}^{2+}$, and $\mathrm{Pb}^{2+}$ ) and oxyanions (e.g., $\mathrm{Cr}_{2} \mathrm{O}_{4}{ }^{2+}$ ) with charged or polar regions of the plastic surface and via non-specific interactions between neutral metal-organic complexes and the hydrophobic surface of the bulk plastic medium. Furthermore, the adsorption capacity of MPs can be varied depending on their morphology, specific surface, or the presence of additives [17].

Physisorption has been identified as an important mechanism of PTEs adsorption on MPs with simple structure and polymer types and MPs with low density of surface functional groups $[9,31]$. However, PTEs adsorption on MPs mainly occurs via chemisorption mechanism, hence, the surface area and the functional groups are highly important. Moreover, electrostatic attraction of positively charged PTEs on negatively charged MPs has been identified (Figure 1) [19,32]. For instance, in a study conducted by Zou et al. [19], the adsorption of $\mathrm{Pb}^{2+}$ onto MPs was mainly governed by electrostatic attraction and that of $\mathrm{Cu}^{2+}$ and $\mathrm{Cd}^{2+}$ was due to both electrostatic attraction and surface complexation. Similarly, Wang et al. [33] studied the $\mathrm{Cu}^{2+}$ adsorption by polyethylene MPs and observed that the highest adsorption $(0.911 \mathrm{mg} / \mathrm{g})$ occurred due to the electrostatic interaction. Furthermore, $\mathrm{Pb}^{2+}$ showed the highest affinity towards the MPs due to the lowest hydrated ionic radius compared to the $\mathrm{Cu}^{2+}$ and $\mathrm{Cd}^{2+}$ [19]. The surface complexation of PTEs was supported by the functional groups $\mathrm{C}-\mathrm{O} / \mathrm{C}=\mathrm{O}[19]$. Moreover, the fourier-transform infrared spectroscopy (FTIR) and X-ray photoelectron spectroscopy (XPS) C $1 \mathrm{~s}$ spectra for polyamide, polyvinyl chloride, polystyrene, acrylonitrile butadiene styrene, and polyethylene terephthalate showed increased $-\mathrm{C}=\mathrm{O}$ functional groups on MPs (except polyvinyl chloride) and a ratio of $-\mathrm{C}=\mathrm{C} /-\mathrm{C}-\mathrm{C}$ in polyamide and acrylonitrile butadiene styrene after the adsorption of $\mathrm{Cd}^{2+}$. Hence, it was clear that the oxygen containing functional groups and cation- $\pi$ electron interaction were vital in $\mathrm{Cd}^{2+}$ adsorption on MPs [34]. In addition, Shen et al. [35] revealed that addition of surfactants increased the hydrophilicity and negative charge of MPs surface, and therefore, increased the adsorption of $\mathrm{Pb}^{2+}$ on MPs. The cationic PTEs sorption also relied on the solution $\mathrm{pH}$. According to a study conducted by Zhou et al. [34], the $\mathrm{Cd}^{2+}$ adsorption on the MPs was increased then decreased in a range of $\mathrm{pH}$ from 6.0 to 9.0. The increased surface negativity which facilitated the electrostatic attraction among $\mathrm{MP}$ and $\mathrm{Cd}^{2+}$ might be the reason for high $\mathrm{Cd}^{2+}$ adsorption at low $\mathrm{pH}$ values [36]. The adsorption of PTEs onto MPs has been described as two steps according to the Weber-Morris model. First, PTEs are rapidly adsorbed onto active sites of MPs via covalent and van der Waals forces; when the adsorption sites are saturated, PTEs are diffused onto the pores of MPs [37].

Scientists also studied the anion adsorption by MPs. For instance, Dong et al. (2020) used Gaussian 16 to simplify the polystyrene structure and revealed that the surface of polystyrene contained positive electrostatic potential $(0-14 \mathrm{kcal} / \mathrm{mol})$. Mainly, the positive electrostatic potential was found in $\mathrm{H}$ atoms located on hydroxyl (i.e., $+46.96 \mathrm{kcal} / \mathrm{mol}$ ) and carboxyl groups (i.e., $+56.60 \mathrm{kcal} / \mathrm{mol}$ ), and it facilitated the adsorption of oxyanions of arsenic [38].

\subsection{Transport of Potentially Toxic Elements via MPs}

The sources of PTEs in the environment are diverse, including natural weathering and mining, industrial effluents, urban runoff, agricultural activities, and many others [39,40]. The most studies have concerned a high load of PTEs on the surface of MPs, documenting the potentiality of MPs as an alternative source or sink of PTEs contaminant in the environment [26]. As discussed above, MPs may correspond to a habitat and transport medium for PTEs. As vectors for PTEs, MPs in particular speed up their transport in diverse environments. Due to the small sizes of MPs, they can easily transfer through sediments, sands, and soils [41], and the micro pores or tunnels formed by plant roots or animal activities may enable the transport of large particles of MPs through the soil column [42]. 


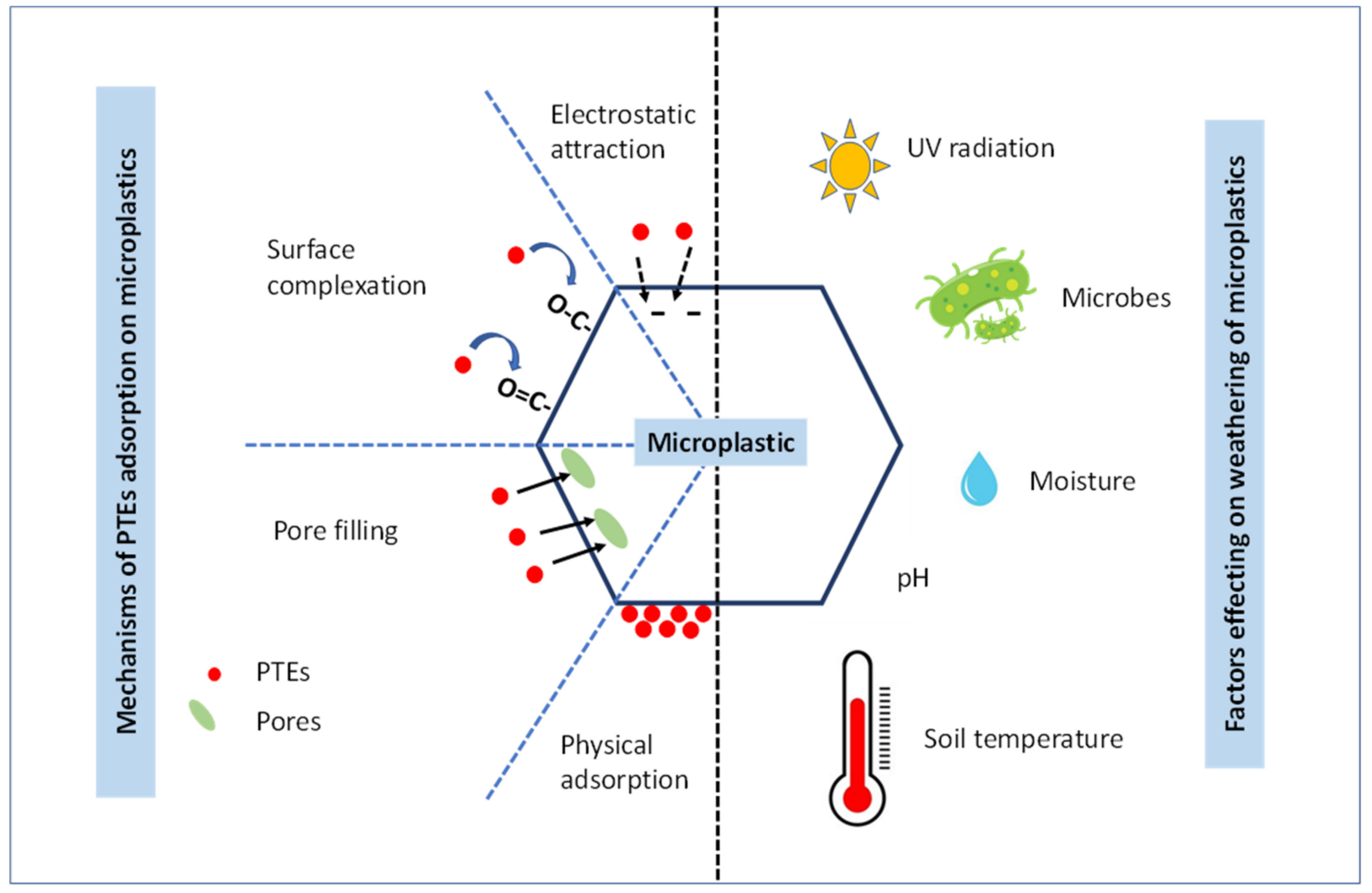

Figure 1. Adsorption mechanisms of potentially toxic elements (PTEs) onto microplastics (MPs). UV: ultraviolet.

The association of PTEs with MPs in aquatic environments primarily depends on the surface properties of MPs and the environmental conditions [43]. Furthermore, the transportation of MPs and attached PTEs in aquatic systems largely depends on the water flow [44]. Therefore, the movement of MPs through the water flow and the adsorption of PTEs on MPs can easily transport the PTEs in the environment. In addition, the PTEs are used as additives in plastics; hence, there is a risk in the releasing of those to the environment. For instance, Garçon et al. [45] observed PTEs leached from 15 different types of disposable protective gloves irrespective of the colors and materials of them. Soaking of gloves for $40 \mathrm{~h}$ in $0.4 \mathrm{M} \mathrm{HNO}_{3}+0.05 \mathrm{M} \mathrm{HF}$ released 60 different types of elements and most of them were belonging to PTEs (i.e., Fe, Hf, Mg, Mn, Pb, Rb, Sr, Sn, Ti, Zr, Ag, As, Ba, Ce, Cr, Cu, Ga, La, Li, Nd, Ni, Sc, Se, Th, Tl, V, and Y). Furthermore, a study conducted by Turner et al. [46] reported bioaccessible concentrations in added $\mathrm{Pb}$ at a range of 20-1200 $\mathrm{mg} \mathrm{g}^{-1}$ in MPs, and it was around $10^{2}-10^{4}$ times higher than that in adsorbed $\mathrm{Pb}$. In addition, different organic additives (e.g., Phthalates, Bisphenol A, Poly-brominated flame retardants, and Nonylphenol) can be released from the MPs, and those also could act as vectors of PTEs $[47,48]$.

Isobe et al. [49] documented that the size and density of MPs also determine the sedimentation and transport in water sources. Furthermore, MPs which had a high density that was greater than the water slowly settled into the sediments. However, special characteristics of MPs affect the sorption/desorption of PTEs and their movement in the aquatic environment and sediments. The relationship of PTEs with MPs seems to be more of a general mechanism concerning different types and sizes of MPs. Thus, MPs might be considered as a vector for the transport of PTEs in aquatic systems [27]. Ultimately, these PTEs either bioaccumulate in food chains or are released back into the environment in a biologically available soluble form. Abbasi et al. [22] documented that PTEs transported by MPs were not native to the plastic but derived from the environment, indicating that the PTEs on the MPs were accumulated from surface sediments; they found that MP particles 
can act as a carrier and transport PTEs to the rhizosphere zone. However, very limited research has concentrated on the interaction between MPs and PTEs.

In recent years the atmospheric transport of MPs has been considered to be an important vector that could accelerate the deposition of MPs onto land or aquatic environments [50]. Atmospheric MPs vary greatly in their shapes; these densities and shapes of MPs particles are important properties in regard to their transportation activities [51]. Moreover, Wang et al. [44] documented the fast sorption/desorption kinetics of airborne contaminants on small-size MPs particles, which are important to adsorb pollutants during the air movement, especially at the cross-boundary movement of MPs. However, the interactions between MPs with PTEs in the atmosphere and their impacts on the environment, humans, and ecosystems are unstudied [52].

\section{The Effect of Environmental Factors on the Adsorption of PTEs onto MPs}

As discussed above, MPs can be carriers of PTEs. Plastic waste in the environment can be weathered and aged due to physical, chemical, and biological factors [11]. Research has explained that many biodegradable plastics are susceptible to disintegration rather than degradation [53]. These processes create MP particles which are $<5 \mathrm{~mm}$; further degradation and disintegration of MPs can generate nanoplastics which are $<0.1 \mu \mathrm{m}$. These micro- and nanoplastics also undergo various weathering processes in the environment due to factors such as ultraviolet radiation, microbial degradation, physical disintegration, and chemical oxidation [54,55], which enhance the oxygen-containing functional groups, hydrophilicity, and surface charge of MPs. Consequently, environmental weathering increases the PTEs adsorption capacity of MPs $[37,55,56]$.

Ultraviolet-radiation-induced weathering is considered to be an important step of the environmental consequences of MPs. MPs absorb ultraviolet radiation and create polymer radicals, followed by surface oxidation. Dong et al. [57] also observed increased surface oxygen content after the environmental weathering of MPs; they suggested that the $\mathrm{O} / \mathrm{C}$ ratio is a reliable indicator of the oxidation degree of MPs. Furthermore, due to this ultraviolet-radiation-induced weathering, polymer chains can be cleaved and form ester, aldehyde, formate, and propyl surface functional groups, which facilitate the adsorption of PETs [24,25]. MPs in the soils can also be subjected to biodegradation, which occurs due to the biochemical transformations mediated by microorganisms. The biodegradation of MPs is facilitated by ultraviolet-radiation-induced weathering, abiotic hydrolysis, and physical disintegration. Those processes increase the surface area and decrease the molecular weight of MPs, which ultimately increase the microbial colonization [25,58]. Environmental conditions such as moisture, temperature, oxygen, and suitable population of microorganisms affect the biodegradation of MPs in soil [59]. For instance, degradation of MPs is enhanced in high moisture contents and high temperatures of soils. In addition, these conditions can also accelerate the ultraviolet-radiation-induced weathering of MPs [25]. However, the MPs weathering and aging under natural conditions are complicated as several agents expose together on MPs particles [60]. Weathered MPs have been shown to have a high adsorption capacity of PTEs due to the high number of surface functional groups, surface area, microcracks, surface roughness, crystallinity, polarity, functional groups, carbonyl index, leachates, and sorption capacity $[38,57,60]$. Furthermore, it has been identified that the adsorption of PTEs increases with the amount of biofilm generated on the surface of MPs [18]. Biofilm formation alter the surface properties of MPs which lead to increase PTEs adsorption via increased wettability, and functional groups due to extracellular polymeric substances of microorganisms [61].

In addition, dissolved organic matter has been identified as a major factor that could increase the adsorption of PTEs onto MPs [17]. Dissolved organic matter increases the adsorption of PTEs onto MPs in two ways. First, PTEs adsorb onto dissolved organic matter, then those make complexes on the surface of MPs. Second, dissolved organic matter constructs a complex with MPs and then adsorbs PTEs [17,62]. Moreover, PTEs can be adsorbed onto the organic matter due to the high density of the surface functional 
groups $[61,63,64]$. The adsorption of PTEs onto MPs also depends on the $\mathrm{pH}$, the presence of ions in the solution $[64,65]$. The $\mathrm{pH}$ of the solution affects the surface charge of MPs and the speciation of PTEs; hence, a prevailing suitable $\mathrm{pH}$ value in the soil will increase the adsorption of PTEs onto MPs. For instance, Li et al. [64] first observed an increase followed by a decrease in the adsorption of $\mathrm{Cd}$ onto microplastics within the $\mathrm{pH}$ range of 5-9 as discussed in Section 2.1. Moreover, authors have observed decreased $\mathrm{Cd}$ adsorption onto MPs with increased ion concentrations. Hence, environmental factors play a major role in the adsorption of PTEs onto MPs in the soil.

\section{Effects of MPs on the Bioaccumulation and Toxicity of PTEs}

During the last hundred years, population growth and industrialization have grown at a fast rate and increased the demand for the exploitation of the Earth's natural resources and synthetic materials like plastics $[66,67]$. Currently, the environment has been seriously polluted by both PTEs and plastics due to those anthropogenic activities [68,69]. Due to the uncontrolled discharge of waste and wastewater containing PTEs from various sources, such as industries, mines, agricultural activities, vehicles, batteries, and PTE-containing paints, their concentration is increased in soils around the world [70,71]. Of particular note is that PTEs are non-biodegradable, considered toxic or carcinogenic ions, tend to accumulate in organisms [72-74], and may destroy enzyme activity, leading to impaired biological growth and metabolism as well as oxidative damage to living beings [75,76]. Moreover, PTEs can bioaccumulate along the food chain and ultimately threaten human health $[77,78]$. At present, research on the combined effects of MPs and PTEs, draws broad attention since MPs act as carriers for PTEs [32,79-82]. In addition, additives in plastics (e.g., pigments, plasticizers, PTEs) have shown potential to leach from aged MPs, releasing potentially hazardous chemicals including PTEs to the soil [83].

\subsection{Microplastic Uptake by Plants}

MPs are abundant throughout the environment and cause considerable concern because micro- and nanoparticles are small enough to be absorbed by many plants in addition to the fact that their potential for bioaccumulation is hazardous because they can permeate biological membranes [84,85]. Agricultural lands in particular are highly vulnerable to MPs due to the application of organic fertilizer coming from municipal solid waste and sewage sludge, organic manures, irrigation, and runoff water, as well as due to intensive agricultural practices like plastic mulching [86]. Furthermore, the MPs are prone to transport processes in soil environment, depending on both physicochemical properties of soils and plastic grain size [87]. In addition, soil macroorganisms are playing an important role in the movement of MPs in soil vertically and into groundwater via casts, burrows, egestion, and adherence organisms' exterior [60]. Therefore, with respect to the human health concern, the absorption mechanism and accumulation process of MPs in individual plants have been studied [88,89]. As shown in Table 1, rice, maize, onion, beans, carrot, corn, oat, lettuce, wheat-like commercial agricultural plants, and other plant species such as grasses and aquatic plants were highly vulnerable to exposed MPs under current anthropogenic activities. Importantly, it was found that MP material was stacked and adsorbed onto the root surface in addition to having entered the shoots of plants through the root system along with water and nutrients, using the transpiration pull of the vascular system [88-90]. The sizes, shapes, and chemical properties of microplastic particles directly affect their translocation in plants [88]. Importantly, MPs are highly potential and are likely to be absorbed by plants' well-developed root systems [89,90]. Furthermore, plants' root growth, movement, and water absorption process greatly influence the migration of MPs [89,91,92]. Based on the above literature, it can be concluded that MPs can enter a plant through the free space between root cells and require a certain transpiration pulling force to reach the aboveground part of the plant. Additionally, MPs might accumulate in the edible and non-edible parts of the plants [93]. However, studies are still lacking on the distribution of microplastics through food chains. 
Table 1. MPs reported in agricultural plants and other plant species.

\begin{tabular}{|c|c|c|c|c|c|}
\hline \multicolumn{3}{|c|}{ Microplastic/Plastic } & \multirow[b]{2}{*}{ Plant } & \multirow[b]{2}{*}{ Effect } & \multirow[b]{2}{*}{ Reference } \\
\hline Types & Size (mm) & $\begin{array}{l}\text { Concentration } \\
\quad(\% w / w)\end{array}$ & & & \\
\hline \multirow{12}{*}{ Polystyrene (PS) } & $0.55 \sim 56$ & 2 & $\begin{array}{l}\text { Onion (Allium } \\
\text { fistulosum) }\end{array}$ & $\begin{array}{l}\text { Increased root biomass, } \\
\text { total root length, and } \\
\text { mean diameter }\end{array}$ & {$[50]$} \\
\hline & $<0.00005$ & - & $\begin{array}{l}\text { Garden onion } \\
\text { (Allium cepa) }\end{array}$ & $\begin{array}{l}\text { The root length was } \\
\text { inhibited }\end{array}$ & [94] \\
\hline & $0.1-0.15$ & $0.1-10$ & Corn (Zea mays) & $\begin{array}{c}\text { Plant root biomass } \\
\text { decreased }\end{array}$ & {$[44]$} \\
\hline & $\mathrm{D}=0.001$ & - & $\begin{array}{l}\text { Garden lettuce } \\
\text { (Lactuaca sativa) }\end{array}$ & $\begin{array}{l}\text { The PS is transported } \\
\text { through the vascular } \\
\text { system to the stem and } \\
\text { leaves }\end{array}$ & [95] \\
\hline & 0.0001 & 5 & $\begin{array}{c}\text { Wheat (Triticum } \\
\text { aestivum) }\end{array}$ & $\begin{array}{l}\text { The root length increased, } \\
\text { the root/shoot ratio } \\
\text { decreased, and the } \\
\text { biomass increased }\end{array}$ & [96] \\
\hline & 5 & - & $\begin{array}{l}\text { Broad bean (Vicia } \\
\qquad f a b a)\end{array}$ & $\begin{array}{l}\text { Decreased biomass and } \\
\text { catalase enzyme activity } \\
\text { in addition to blocking cell } \\
\text { connections or cell wall } \\
\text { pores for the transport of } \\
\text { nutrients in roots }\end{array}$ & [89] \\
\hline & $\mathrm{D}=<0.001$ & - & Rice (Oryza sativa) & $\begin{array}{l}\text { PS was mostly aggregated } \\
\text { in the vascular systems of } \\
\text { the roots, stems, and } \\
\text { leaves, with a high } \\
\text { possibility of entering the } \\
\text { food chain }\end{array}$ & [97] \\
\hline & $<50$ & - & Rice (Oryza sativa) & $\begin{array}{l}\text { Higher doses of PS caused } \\
\mathrm{a} \approx 40 \% \text { decrease in shoot } \\
\text { biomass }\end{array}$ & [98] \\
\hline & 0.01 & - & Rice (Oryza sativa) & $\begin{array}{l}\text { Affected the transpiration } \\
\text { and stomata of rice } \\
\text { seedlings primarily via } \\
\text { inhibiting their root vigor }\end{array}$ & [99] \\
\hline & $<0.048$ & - & $\begin{array}{c}\text { Garden cress } \\
\text { (Lepidium sativum) }\end{array}$ & $\begin{array}{l}\text { Significantly declined } \\
\text { germination rate and } \\
\text { inhibited plant growth }\end{array}$ & [88] \\
\hline & $<0.001$ & - & $\begin{array}{l}\text { Carrot (Daucus } \\
\text { carota L.) }\end{array}$ & $\begin{array}{l}\text { Entered the roots and } \\
\text { accumulated in the } \\
\text { intercellular layer; } \\
\text { particles were able to } \\
\text { translocate to the leaves }\end{array}$ & [90] \\
\hline & 0.001 & - & $\begin{array}{l}\text { Lettuce (Lactuca } \\
\text { sativa L., Rosa) }\end{array}$ & $\begin{array}{c}\text { Adherence, uptake, } \\
\text { accumulation, and } \\
\text { translocation of PS in the } \\
\text { vascular tissue }\end{array}$ & [100] \\
\hline
\end{tabular}


Table 1. Cont.

\begin{tabular}{|c|c|c|c|c|c|}
\hline \multicolumn{3}{|c|}{ Microplastic/Plastic } & \multirow[b]{2}{*}{ Plant } & \multirow[b]{2}{*}{ Effect } & \multirow[b]{2}{*}{ Reference } \\
\hline Types & Size (mm) & $\begin{array}{l}\text { Concentration } \\
\quad(\% w / w)\end{array}$ & & & \\
\hline \multirow{5}{*}{$\begin{array}{l}\text { Low density } \\
\text { polyethylene } \\
\text { (LDPE) }\end{array}$} & L: 4-10 & 1 & $\begin{array}{l}\text { Garden lettuce } \\
\text { (Lactuaca sativa) }\end{array}$ & $\begin{array}{l}\text { The total biomass } \\
\text { decreased and the } \\
\text { composition of the } \\
\text { rhizosphere bacterial } \\
\text { community changed }\end{array}$ & [95] \\
\hline & $\mathrm{L}=6.9 ; \mathrm{W}=6.1$ & 1 & $\begin{array}{l}\text { Wheat (Triticum } \\
\text { aestivum) }\end{array}$ & $\begin{array}{c}\text { The fruit biomass and leaf } \\
\text { number decreased }\end{array}$ & [101] \\
\hline & - & 1 & $\begin{array}{l}\text { Wheat (Triticum } \\
\text { aestioum) }\end{array}$ & $\begin{array}{l}\text { Affected vegetative and } \\
\text { reproductive growth }\end{array}$ & [102] \\
\hline & $0.053-1$ & $0.2-2.5$ & $\begin{array}{l}\text { Bean (Phaseolus } \\
\text { vulgaris) }\end{array}$ & $\begin{array}{l}\text { Aboveground and root } \\
\text { biomass affected but the } \\
\text { effect was not significant }\end{array}$ & [91] \\
\hline & $\mathrm{L}=5, \mathrm{~W}=5$ & $0.1-0.4$ & $\begin{array}{l}\text { Carrot (Daucus } \\
\text { carota) }\end{array}$ & $\begin{array}{l}\text { Aboveground biomass } \\
\text { and root mass decreased } \\
\text { with increasing } \\
\text { concentration }\end{array}$ & [103] \\
\hline \multirow{3}{*}{$\begin{array}{l}\text { Poly lactic acid } \\
\text { (PLA) }\end{array}$} & $0.1-0.15$ & $0.1-10$ & Corn (Zea mays) & $\begin{array}{l}\text { High concentration of } \\
\text { PLA significantly reduced } \\
\text { plant biomass }\end{array}$ & [15] \\
\hline & 0.065 & $0.1-0.001$ & $\begin{array}{l}\text { Perennial ryegrass } \\
\text { (Lolium perenne) }\end{array}$ & $\begin{array}{l}\text { Reduced shoot height and } \\
\text { biomass }\end{array}$ & [16] \\
\hline & - & - & $\begin{array}{c}\text { Bean (Phaseolus } \\
\text { vulgaris) }\end{array}$ & $\begin{array}{l}\text { Root and aboveground } \\
\text { biomass reduced }\end{array}$ & [91] \\
\hline \multirow{3}{*}{ Polyethylene (PE) } & $\mathrm{D}=0.2-0.25$ & $0.5-8.0$ & $\begin{array}{l}\text { Wheat (Triticum } \\
\text { aestivum L.) }\end{array}$ & $\begin{array}{l}\text { A high concentration of } \\
\text { PE damaged the } \\
\text { antioxidant system in } \\
\text { wheat roots }\end{array}$ & [104] \\
\hline & 0.003 & - & Corn (Zea mays) & $\begin{array}{l}\text { PE reduced or blocked } \\
\text { water and nutrient uptake } \\
\text { as well as the growth of } \\
\text { the maize plant }\end{array}$ & [105] \\
\hline & 0.5 & $0.1-10$ & $\begin{array}{l}\text { Lettuce (Lactuca } \\
\text { sativa L.) }\end{array}$ & $\begin{array}{l}\text { Increased the toxicity, } \\
\text { uptake, accumulation, and } \\
\text { bioavailability of heavy } \\
\text { metals }\end{array}$ & [93] \\
\hline \multirow{2}{*}{$\begin{array}{l}\text { High density } \\
\text { polyethylene } \\
\text { (HDPE) }\end{array}$} & - & $0.1-0.001$ & $\begin{array}{l}\text { Carrot (Daucus } \\
\text { carota) }\end{array}$ & $\begin{array}{c}\text { Shoot height and biomass } \\
\text { reduced, fewer seeds } \\
\text { germinated }\end{array}$ & [16] \\
\hline & $0.01-0.15$ & $0.1-10$ & & $\begin{array}{l}\text { There was no significant } \\
\text { change in plant biomass }\end{array}$ & [103] \\
\hline \multirow[t]{2}{*}{ Polyamide (PA) } & $0.015-0.02$ & 2 & $\begin{array}{l}\text { Onion (Allium } \\
\text { fistulosum) }\end{array}$ & $\begin{array}{l}\text { Significantly affected plant } \\
\text { biomass, root traits, tissue } \\
\text { elemental composition, } \\
\text { and soil microbial activity }\end{array}$ & [50] \\
\hline & $0.015-0.02$ & 2 & $\begin{array}{l}\text { Wheat (Triticum } \\
\text { aestivum) }\end{array}$ & $\begin{array}{l}\text { The total biomass } \\
\text { increased as did the total } \\
\text { root length and mean } \\
\text { diameter }\end{array}$ & [96] \\
\hline
\end{tabular}


Table 1. Cont.

\begin{tabular}{|c|c|c|c|c|c|}
\hline \multicolumn{3}{|c|}{ Microplastic/Plastic } & \multirow[b]{2}{*}{ Plant } & \multirow[b]{2}{*}{ Effect } & \multirow[b]{2}{*}{ Reference } \\
\hline Types & Size (mm) & $\begin{array}{l}\text { Concentration } \\
\quad(\% \text { w/w) }\end{array}$ & & & \\
\hline \multirow[b]{2}{*}{ Polypropylene (PP) } & - & 0.02 & $\begin{array}{c}\text { Garden cress } \\
\text { (Lepidium sativum) }\end{array}$ & $\begin{array}{l}\text { Occurrence of oxidative } \\
\text { burst }\end{array}$ & [106] \\
\hline & $\mathrm{L}=5, \mathrm{~W}=5$ & $0.1-0.4$ & $\begin{array}{l}\text { Carrot (Daucus } \\
\text { carota) }\end{array}$ & $\begin{array}{l}\text { Aboveground biomass } \\
\text { and root mass decreased } \\
\text { with increasing } \\
\text { concentration }\end{array}$ & [103] \\
\hline \multirow{2}{*}{$\begin{array}{l}\text { Polyester fibers } \\
\text { (PFs) }\end{array}$} & $\mathrm{L}=5, \mathrm{D}=0.008$ & 0.2 & $\begin{array}{l}\text { Onion (Allium } \\
\text { fistulosum) }\end{array}$ & $\begin{array}{l}\text { Significantly changed } \\
\text { plant biomass, root } \\
\text { traits, tissue elemental } \\
\text { composition, and soil } \\
\text { microbial activity }\end{array}$ & [50] \\
\hline & $\mathrm{L}=1.3, \mathrm{D}=0.03$ & - & $\begin{array}{l}\text { Grasses (Festuca } \\
\text { brevipila) and herbs } \\
\text { (Achillea } \\
\text { millefolium) }\end{array}$ & Decreased biomass & [107] \\
\hline \multirow[t]{2}{*}{$\begin{array}{l}\text { Polyether sulfone } \\
\text { (PES) }\end{array}$} & $\mathrm{L}=5, \mathrm{D}=0.008$ & 0.2 & $\begin{array}{l}\text { Onion (Allium } \\
\text { fistulosum) }\end{array}$ & $\begin{array}{l}\text { The total biomass and } \\
\text { root biomass increased, } \\
\text { the total root length and } \\
\text { mean diameter } \\
\text { increased, and the root } \\
\text { microbial activity } \\
\text { increased }\end{array}$ & [50] \\
\hline & $\mathrm{L}=1.3, \mathrm{D}=0.03$ & 0.4 & $\begin{array}{l}\text { Wood small-reed } \\
\text { (Calamagrostis } \\
\text { epigejos) }\end{array}$ & $\begin{array}{l}\text { The root biomass } \\
\text { increased }\end{array}$ & [107] \\
\hline $\begin{array}{c}\text { Expandable } \\
\text { polystyrene (EPS) }\end{array}$ & 8.3 & - & $\begin{array}{c}\text { Mung bean } \\
\text { (Phaseolus radiates), } \\
\text { lettuce (Lactuca } \\
\text { sativa), and rice } \\
\text { (Oryza sativa) }\end{array}$ & $\begin{array}{l}\text { Low levels of interaction } \\
\text { with the crop dependent } \\
\text { and water absorption } \\
\text { rate }\end{array}$ & [92] \\
\hline $\begin{array}{l}\text { Polyvinyl chloride } \\
\text { (PVC) }\end{array}$ & $0.018-0.15$ & $0.5-2$ & $\begin{array}{l}\text { Lettuce (Lactuva } \\
\text { sativa L.) }\end{array}$ & $\begin{array}{l}\text { PCV-a promoted } \\
\text { carotenoid synthesis } \\
\text { whereas PVC-b } \\
\text { inhibited it }\end{array}$ & [95] \\
\hline $\begin{array}{l}\text { Melamine phenolic } \\
(\mathrm{MP})\end{array}$ & 0.0048 & - & $\begin{array}{c}\text { Garden cress } \\
\text { (Lepidium sativum) }\end{array}$ & $\begin{array}{l}\text { Accumulated on the root } \\
\text { hairs, the germination } \\
\text { rate was significantly } \\
\text { reduced, and pores in } \\
\text { the seed capsule were } \\
\text { physically blocked }\end{array}$ & [88] \\
\hline $\begin{array}{l}\text { Polyetherimide } \\
\text { (PEIs) }\end{array}$ & - & $0.01-0.1$ & $\begin{array}{l}\text { Oat (Avena sativa) } \\
\quad \text { and radish } \\
\text { (Raphanus sativus) }\end{array}$ & $\begin{array}{l}\text { Nitrogen released from } \\
\text { the tested PEIs but no } \\
\text { harmful effect; harmful } \\
\text { to plants only at high } \\
\text { concentrations }\end{array}$ & [108] \\
\hline
\end{tabular}

\subsection{Effect of MPs on Soil Animals and Microbial Activity}

Soil contamination due to microplastics might affect the physical, chemical, and biological properties of soil. This might significantly influence the functional and structural diversity of soil animals (earthworms, insects, and spiders) and microbial communities (bacteria, fungi, and protozoa), causing serious damage to the agricultural soil [50,109,110] (Figure 2). 
These changes in soil properties and composition directly affect the fertility of the soil by decreasing the growth and activities of soil animals and microbial communities $[75,90,111]$. The soil is an important boundary where plants act together with beneficial and harmful microbial communities. The pollution of soil by high-density polyethylene (HDPE) decreases soil $\mathrm{pH}$, which might impact microbial growth and functions $[16,112]$. Interestingly, recent studies have reported an increase in soil $\mathrm{pH}$ and a reduction in soil electrical conductivity in polyethylene (PE)-, polylactic acid (PLA)-, and low-density polyethylene (LDPE)-contaminated soils [44,111]. Changes in soil $\mathrm{pH}$ are highly influenced by variations in soil microbial communities [104]. Furthermore, a few studies have discovered adverse effects of polystyrene (PS) particles on microbial activities in the soil as well $[113,114]$. Despite the above, the mechanism of $\mathrm{pH}$ change in soil caused by the contamination of MPs is still unclear [115]. Thus, more studies are recommended to understand the changes in $\mathrm{pH}$ under the influence of MPs. Interestingly, polypropylene (PP) was found to have a positive impact on bacterial growth in the soil [116]. Wang et al. [44] reported that microplastic particles affect the abundance of arbuscular mycorrhizal fungi in the soil. Additionally, Chen et al. [117] reported that poly lactic acid (PLA) affects microbial-supported mineral absorption and nitrogen fixation rates. In addition, Fei et al. [118] found that polyethylene (PE) and polyvinyl chloride (PVC) encourage acid phosphatase and urease activity in soil. Similarly, Huang et al. [119] exposed the fact that microplastics provide exceptional habitats for some microbial communities, such as pathogens and plastic-degrading bacteria. In addition, studies showed that due to the changes in microbial community composition in soils, the nutrient cycling also can be significantly altered. For instance, Seeley et al. observed polyurethane foam or polylactic acid MPs amended sediments increased nitrification and denitrification, while that of decreased by polyvinyl chloride MPs. Those results imply that the nitrogen cycle in sediments can be significantly impacted by MPs, as MPs are serving as organic carbon substrates for microbial growth [120]. However, the interaction of soil animals and microorganisms with MPs largely remains unexplored. Thus, the limited information available on general microbial activity in soil is influenced by MPs. Therefore, further investigations are strongly recommended to understand the positive and negative effects of microplastics on soil animals' and microorganisms' activities in the soil.

\subsection{MP Accumulation in Plants and Toxicity}

The MPs act as vectors and sinks of toxic organic as well as inorganic pollutants. The accumulation of MPs in plants could pose a potential human health risk. The accumulation and transmission of MPs in the food chain is an important way for them to be exposed to the human body $[121,122]$. Researchers have reported the possible accumulation of MPs in rice [85], lettuce [93], carrot [90], wheat [102], mung bean [123], and beans [89,91]. Therefore, the risk of bioaccumulation of MPs through the food chain is very high, ultimately threatening human health. Importantly, MPs have strong hydrophobicity and a strong adsorption capacity for heavy metals, organic pollutants, pharmaceuticals, pesticides, herbicides, weedicides, and insecticides, very hazardous substances from agricultural soils. Thus, through food chains, MP particles can enter the human body and might enter human organs through the circulatory system [124]. Currently, only a limited number of studies have focused on the size of MPs as a significant factor for plant toxicity $[88,89,102]$. Few authors have reported the effect of the shape of MPs on plant toxicity [16,50]. Furthermore, the surface charges of available materials in soil and the chemical configuration of MPs are important factors that govern the uptake and toxicity of MPs in plant species [50,102,125]. Qi et al. [111] reported that biodegradable MPs can harmfully influence biometric parameters in wheat at the vegetative and reproductive phases. In addition, Jiang et al. [89] reported that MPs encouraged ecotoxicity and genotoxicity in plants. Similar type of experimental results were reported by a few authors on the effect of MP toxicity on plant growth and performance of lettuce [126], maize [127], rice [99], and maize [16] productivity. The MP particles concentrated in the soil are possibly adsorbed to the belowground parts of plants, which might lead to reaching absorbed MPs into the root eaters' body [89]. Impor- 
tantly, MPs can alter the evapotranspiration of plants and contribute to a more pronounced drought condition [128]. This modification in the metabolic system affected a weakening in the harvest yield. Boots et al. [16] noticed that MPs damagingly influence the growth of above and belowground parts of plants. Zhang et al. [52] reported on the influence of MPs on the absorption of $\mathrm{Cd}$ in agricultural soil and mentioned that higher concentrations of MPs caused higher absorption of PTEs in addition to possible risks to plants and animals. Thus, MP deposits and particles serve as vectors for other pollutants. These contaminants, after absorbing and accumulating into plants, might lead to a possible path into the food chain. They might govern the bioaccumulation of MPs and other pollutants, which can lead to major health risks. Based on the above literature, the bioaccumulation of MPs affects plants' agricultural productivity and animals' health. Therefore, intensive management and clear policy are required to manage the pollution of MPs in agricultural soils.

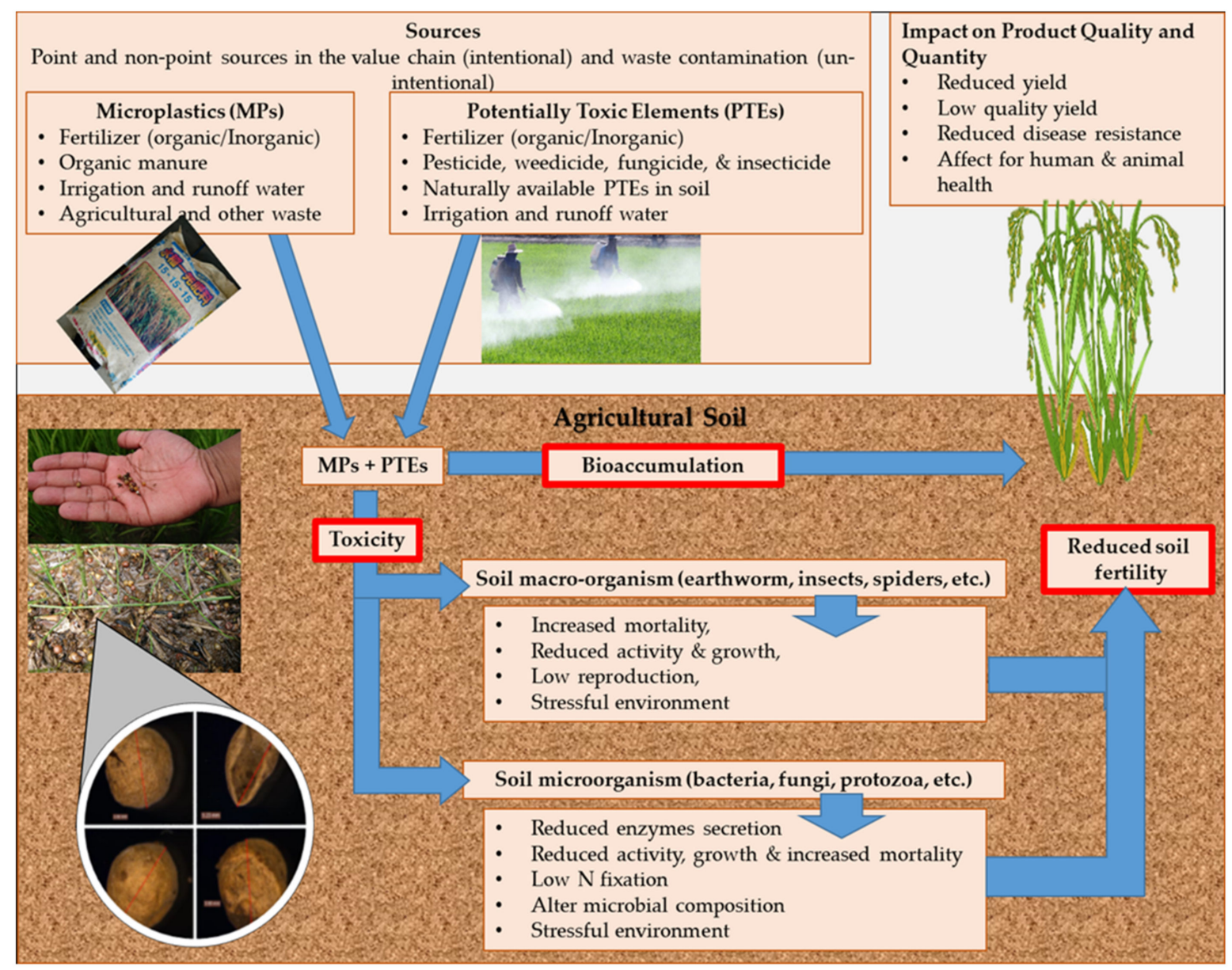

Figure 2. Exposure and bioaccumulation of MPs and PTEs in agricultural soil.

\section{Policy and Governance Measures}

Necessary policies and institutionalized governance measures could be key drivers in creating appropriate barriers to MPs entering humans through food chains [129] and thus, the PTEs associated with MPs as well. Furthermore, the integration of 3R and circular economy approaches while restricting the release, recontamination, and spread of MPs and PTEs into the environment could support the mitigation process. Present plastic waste management policies mainly focus on waste disposal and regulation on land while the policies regarding MPs have largely been focused on the prevention of aquatic MP pollution [130]. International and national agencies working on environmental protection and conservation have intervened in the determination of policies and regulations to protect aquatic environments from the harmful impacts of MPs [131,132]. However, attention is 
growing on the detrimental impacts of MPs in terrestrial systems and the dialog surrounding mitigative policy measures $[130,133]$. This would support the measures intended to mitigate the contamination of agricultural lands by MPs and PTEs as well as human exposure to them through food chains that originate in land-based agriculture. As elaborated on in Section 4.1, the major contamination pathways, such as irrigation water, fertilizers, and soil conditioners, including sewage sludge, are to be considered in the countermeasuring policies and institutionalization process. For example, the Basel Convention Plastic Waste Amendments, 2019, for the international movement of plastic waste [134] can be further strengthened to include products related to agriculture, such as soil amendments and compost. Figure 3 illustrates the policy- and governance-based countermeasures for MPs and PTEs that reach humans through ingestion. The California State Legislature enacted two bills that require the quantification of MPs in various media and the development of new management strategies to address MP pollution, targeting the mitigation of human exposure through ingestion [135]. The case of California is a classic example of recent policy developments instituted to tackle the contamination of humans by MPs via ingestion.

As discussed in previous sections, the management of sewage sludge plays an important role in the management of the recontamination of agricultural lands by MP-associated PTEs. In particular, practices such as open dumping, added as a soil improvement and used as a fertilizer for crops, lead to recontamination by MPs and associated PTEs. However, so far, policy measures that directly target the link between MPs and sewage sludge are not reflected in policy around the world [136]. Nevertheless, the land application of sewage sludge is regulated and institutionalized in several European Union (EU) countries, where these management practices indirectly restrict soil recontamination [136]. For example, the sewage sludge ordinance in Germany states that sewage sludge from WWTP will not be permitted for direct use as a fertilizer from 2029. However, many other countries around the world, especially in Asia-Pacific, Africa, and the Americas, use open landfilling or agricultural land application as a primary method of sewage sludge disposal [137]. Furthermore, despite the presence of scientific literature on plastic-pollution-related policy measures in developing countries, policies targeting the contamination of agricultural land by microplastics are limited. For example, the review of [138] on plastic-related policies for Africa summarizes them, yet there are no policies that aim to restrict the contamination of agricultural land and plant intake.

Apart from sewage sludge, other forms of organic fertilizers, as discussed previously, can be a major source of microplastics due to contamination at the source, during production, or post-production, such as packaging. Since it is practically impossible to decontaminate microplastics during manufacturing processes, such as the composting of organic fertilizer, the feasible approach is minimization by implementing proper source separation. Furthermore, proper quality assurance measures should be taken to ensure feedstock quality, production process quality, and post-production quality.

Plastic-coated fertilizer (or controlled-released fertilizers, considering the function from agricultural perspectives) is a classic example of the direct intentional application of MPs into agricultural lands over the last two decades, the consequent effects and accumulations of which are now being reported [10]. In the context of environmental pollution, these plastic-coated fertilizers are reported to decrease total fertilizer usage by $20-30 \%$ and minimize the environmental leakage of nutrients while increasing productivity [139].

Hence, the implementation of policies and governance measures shall be considered the complete life cycle impacts of the products, process, and alternative scenarios. The measures shall target 3R- and various circular-economy-based approaches after assessing the situation. Deng et al. [140] suggested policy measures to reduce the production of MPs and promote public willingness for recycling strategy applications. Apart from this, countermeasures must be for managing plastic litter (as a source of secondary MPs) and MPs with public participation, including citizen science contributions [141]. 


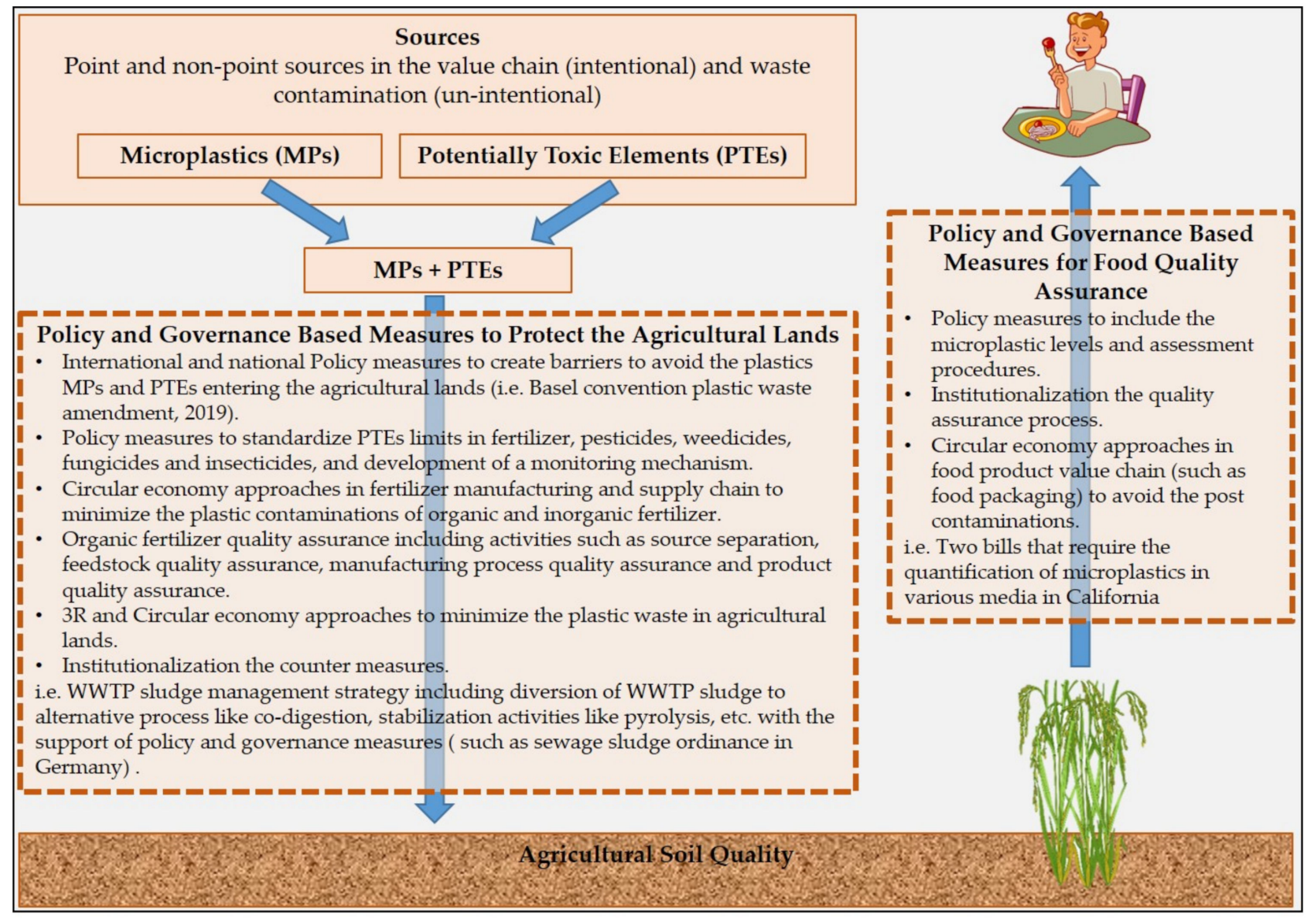

Figure 3. Policy and governance-based countermeasures.

\section{Conclusions}

PTEs adsorb onto MPs through physicochemical interactions and increase their mobility in soils. Hence, MPs act as vectors for PTEs in soil. MP and PTE complexes can be easily adsorbed by plants. Therefore, the accumulation of PTEs in plants can be enhanced in both MP- and PTE-contaminated soils. Furthermore, there is a high risk of food chain contamination with PTEs by crops grown in both MP- and PTE-contaminated soils. Certain intentional (i.e., controlled-release fertilizer) and unintentional (i.e., Sewage sludge application), agricultural applications are identified sources of contamination of agricultural lands. Policy- and governance-based countermeasures shall focus on both agricultural land quality assurance and food quality assurance to minimize human exposure due to the ingestion of PTEs related to MPs.

Author Contributions: Conceptualization, A.D.I., M.G.Y.L.M., P.G., A.A. and P.J.D.G.; methodology, A.D.I.; investigation, A.D.I., M.G.Y.L.M. and P.G.; resources, A.A. and P.J.D.G.; data curation, A.D.I. and P.G.; writing - original draft preparation, A.D.I., M.G.Y.L.M., P.G. and A.A.; writing-review and editing, A.D.I., M.G.Y.L.M., P.G., A.A., P.J.D.G., M.T., M.O., T.F. and N.I.; visualization, A.D.I. and A.A.; supervision, A.A. and P.J.D.G.; project administration, A.A. Funding acquisition, P.J.D.G. and A.A. All authors have read and agreed to the published version of the manuscript.

Funding: The manuscript preparation expenses were partially funded by Institute for Global Environmental Strategies (IGES), Japan.

Conflicts of Interest: The authors declare no conflict of interest. The funders had no role in the design of the study; in the collection, analyses, or interpretation of data; in the writing of the manuscript, or in the decision to publish the review. 


\section{References}

1. Adyel, T.M. Accumulation of Plastic Waste during COVID-19. Science 2020, 369, 1314-1315. [PubMed]

2. Benson, N.U.; Bassey, D.E.; Palanisami, T. COVID Pollution: Impact of COVID-19 Pandemic on Global Plastic Waste Footprint. Heliyon 2021, 7, e06343. [CrossRef] [PubMed]

3. Prata, J.C.; Silva, A.L.P.; Walker, T.R.; Duarte, A.C.; Rocha-Santos, T. COVID-19 Pandemic Repercussions on the Use and Management of Plastics. Environ. Sci. Technol. 2020, 54, 7760-7765. [CrossRef]

4. Bergmann, M.; Mützel, S.; Primpke, S.; Tekman, M.B.; Trachsel, J.; Gerdts, G. White and Wonderful? Microplastics Prevail in Snow from the Alps to the Arctic. Sci. Adv. 2019, 5, 1-10. [CrossRef]

5. $\quad$ Brodhagen, M.; Goldberger, J.R.; Hayes, D.G.; Inglis, D.A.; Marsh, T.L.; Miles, C. Policy Considerations for Limiting Unintended Residual Plastic in Agricultural Soils. Environ. Sci. Policy 2017, 69, 81-84. [CrossRef]

6. Corradini, F.; Meza, P.; Eguiluz, R.; Casado, F.; Huerta-Lwanga, E.; Geissen, V. Evidence of Microplastic Accumulation in Agricultural Soils from Sewage Sludge Disposal. Sci. Total Environ. 2019, 671, 411-420. [CrossRef] [PubMed]

7. Dris, R.; Gasperi, J.; Saad, M.; Mirande, C.; Tassin, B. Synthetic Fibers in Atmospheric Fallout: A Source of Microplastics in the Environment? Mar. Pollut. Bull. 2016, 104, 290-293. [CrossRef]

8. Abeynayaka, A.; Werellagama, I.; Ngoc-Bao, P.; Hengesbaugh, M.; Gajanayake, P.; Nallaperuma, B.; Karkour, S.; Xuan-Thanh, B.; Itsubo, N. Microplastics in Wastewater Treatment Plants; Bui, X.-T., Nguyen, D.D., Nguyen, P.D., Ngo, H.H., Pandey, A., Eds.; Elsevier: Amsterdam, The Netherlands, 2022.

9. Wang, J.; Liu, X.; Li, Y.; Powell, T.; Wang, X.; Wang, G.; Zhang, P. Microplastics as Contaminants in the Soil Environment: A Mini-Review. Sci. Total Environ. 2019, 691, 848-857. [CrossRef] [PubMed]

10. Katsumi, N.; Kusube, T.; Nagao, S.; Okochi, H. Accumulation of Microcapsules Derived from Coated Fertilizer in Paddy Fields. Chemosphere 2021, 267, 129185. [CrossRef]

11. De Souza Machado, A.A.; Kloas, W.; Zarfl, C.; Hempel, S.; Rillig, M.C. Microplastics as an Emerging Threat to Terrestrial Ecosystems. Glob. Chang. Biol. 2018, 24, 1405-1416. [CrossRef]

12. Serrano-Ruiz, H.; Martin-Closas, L.; Pelacho, A.M. Biodegradable Plastic Mulches: Impact on the Agricultural Biotic Environment. Sci. Total Environ. 2021, 750, 141228. [CrossRef]

13. Kumar, M.; Xiong, X.; He, M.; Tsang, D.C.W.; Gupta, J.; Khan, E.; Harrad, S.; Hou, D.; Ok, Y.S.; Bolan, N.S. Microplastics as Pollutants in Agricultural Soils. Environ. Pollut. 2020, 265, 114980. [CrossRef]

14. Nizzetto, L.; Langaas, S.; Futter, M. Pollution: Do Microplastics Spill on to Farm Soils? Nature 2016, 537, 488. [CrossRef]

15. Wang, T.; Wang, L.; Chen, Q.; Kalogerakis, N.; Ji, R.; Ma, Y. Interactions between Microplastics and Organic Pollutants: Effects on Toxicity, Bioaccumulation, Degradation, and Transport. Sci. Total Environ. 2020, 748, 142427. [CrossRef]

16. Boots, B.; Russell, C.W.; Green, D.S. Effects of Microplastics in Soil Ecosystems: Above and below Ground. Environ. Sci. Technol. 2019, 53, 11496-11506. [CrossRef]

17. Godoy, V.; Blázquez, G.; Calero, M.; Quesada, L.; Martín-Lara, M.A. The Potential of Microplastics as Carriers of Metals. Environ Pollut. 2019, 255, 113363. [CrossRef]

18. Richard, H.; Carpenter, E.J.; Komada, T.; Palmer, P.T.; Rochman, C.M. Biofilm Facilitates Metal Accumulation onto Microplastics in Estuarine Waters. Sci. Total Environ. 2019, 683, 600-608. [CrossRef]

19. Zou, J.; Liu, X.; Zhang, D.; Yuan, X. Adsorption of Three Bivalent Metals by Four Chemical Distinct Microplastics. Chemosphere 2020, 248, 126064. [CrossRef]

20. Hou, D.; O'Connor, D.; Igalavithana, A.D.; Alessi, D.S.; Luo, J.; Tsang, D.C.W.; Sparks, D.L.; Yamauchi, Y.; Rinklebe, J.; Ok, Y.S. Metal Contamination and Bioremediation of Agricultural Soils for Food Safety and Sustainability. Nat. Rev. Earth Environ. 2020, 1, 366-381. [CrossRef]

21. Igalavithana, A.D.; Kwon, E.E.; Vithanage, M.; Rinklebe, J.; Moon, D.H.; Meers, E.; Tsang, D.C.W.; Ok, Y.S. Soil Lead Immobilization by Biochars in Short-Term Laboratory Incubation Studies. Environ. Int. 2019, 127, 190-198. [CrossRef]

22. Abbasi, S.; Moore, F.; Keshavarzi, B.; Hopke, P.K.; Naidu, R.; Rahman, M.M.; Oleszczuk, P.; Karimi, J. PET-Microplastics as a Vector for Heavy Metals in a Simulated Plant Rhizosphere Zone. Sci. Total Environ. 2020, 744, 140984. [CrossRef]

23. Khalid, N.; Aqeel, M.; Noman, A. Microplastics Could Be a Threat to Plants in Terrestrial Systems Directly or Indirectly. Environ. Pollut. 2020, 267, 115653. [CrossRef]

24. Gewert, B.; Plassmann, M.M.; MacLeod, M. Pathways for Degradation of Plastic Polymers Floating in the Marine Environment. Environ. Sci. Process. Impacts 2015, 17, 1513-1521. [CrossRef] [PubMed]

25. Singh, B.; Sharma, N. Mechanistic Implications of Plastic Degradation. Polym. Degrad. Stab. 2008, 93, 561-584. [CrossRef]

26. Verla, A.W.; Enyoh, C.E.; Verla, E.N.; Nwarnorh, K.O. Microplastic-Toxic Chemical Interaction: A Review Study on Quantified Levels, Mechanism and Implication. SN Appl. Sci. 2019, 1, 1400. [CrossRef]

27. Holmes, L.A.; Turner, A.; Thompson, R.C. Adsorption of Trace Metals to Plastic Resin Pellets in the Marine Environment. Environ. Pollut. 2012, 160, 42-48. [CrossRef] [PubMed]

28. Mohsen, M.; Wang, Q.; Zhang, L.; Sun, L.; Lin, C.; Yang, H. Heavy Metals in Sediment, Microplastic and Sea Cucumber Apostichopus Japonicus from Farms in China. Mar. Pollut. Bull. 2019, 143, 42-49. [CrossRef] [PubMed]

29. Zhang, Z.X.; Chen, C.H.; Gao, X.W.; Kim, J.K.; Xin, Z.X. A Study on the Compatibility and Physical Properties of Chlorinated Polyethylene Rubber/Nitrile Rubber Blends. J. Appl. Polym. Sci. 2011, 120, 1180-1185. [CrossRef] 
30. Gasperi, J.; Wright, S.L.; Dris, R.; Collard, F.; Mandin, C.; Guerrouache, M.; Langlois, V.; Kelly, F.J; Tassin, B. Microplastics in Air: Are We Breathing It In? Curr. Opin. Environ. Sci. Health 2018, 1, 1-5. [CrossRef]

31. Gao, X.; Hassan, I.; Peng, Y.; Huo, S.; Ling, L. Behaviors and Influencing Factors of the Heavy Metals Adsorption onto Microplastics: A Review. J. Clean. Prod. 2021, 319, 128777. [CrossRef]

32. Khalid, N.; Aqeel, M.; Noman, A.; Khan, S.M.; Akhter, N. Interactions and Effects of Microplastics with Heavy Metals in Aquatic and Terrestrial Environments. Environ. Pollut. 2021, 290, 118104. [CrossRef]

33. Wang, Y.; Wang, X.; Li, Y.; Li, J.; Wang, F.; Xia, S.; Zhao, J. Biofilm Alters Tetracycline and Copper Adsorption Behaviors onto Polyethylene Microplastics. Chem. Eng. J. 2020, 392, 123808. [CrossRef]

34. Zhou, Y.; Yang, Y.; Liu, G.; He, G.; Liu, W. Adsorption Mechanism of Cadmium on Microplastics and Their Desorption Behavior in Sediment and Gut Environments: The Roles of Water PH, Lead Ions, Natural Organic Matter and Phenanthrene. Water Res. 2020, 184, 116209. [CrossRef]

35. Shen, M.; Song, B.; Zeng, G.; Zhang, Y.; Teng, F.; Zhou, C. Surfactant Changes Lead Adsorption Behaviors and Mechanisms on Microplastics. Chem. Eng. J. 2021, 405, 126989. [CrossRef]

36. Wang, Q.; Zhang, Y.; Wangjin, X.; Wang, Y.; Meng, G.; Chen, Y. The Adsorption Behavior of Metals in Aqueous Solution by Microplastics Effected by UV Radiation. J. Environ. Sci. 2020, 87, 272-280. [CrossRef]

37. Guo, X.; Hu, G.; Fan, X.; Jia, H. Sorption Properties of Cadmium on Microplastics: The Common Practice Experiment and A Two-Dimensional Correlation Spectroscopic Study. Ecotoxicol. Environ. Saf. 2020, 190, 110118. [CrossRef]

38. Dong, Y.; Gao, M.; Song, Z.; Qiu, W. As(III) Adsorption onto Different-Sized Polystyrene Microplastic Particles and Its Mechanism. Chemosphere 2020, 239, 124792. [CrossRef]

39. Jiang, S.; Huang, L.; Nguyen, T.A.H.; Ok, Y.S.; Rudolph, V.; Yang, H.; Zhang, D. Copper and Zinc Adsorption by Softwood and Hardwood Biochars under Elevated Sulphate-Induced Salinity and Acidic PH Conditions. Chemosphere 2016, $142,64-71$. [CrossRef]

40. Yang, X.; Igalavithana, A.D.; Oh, S.-E.; Nam, H.; Zhang, M.; Wang, C.-H.; Kwon, E.E.; Tsang, D.C.W.; Ok, Y.S. Characterization of Bioenergy Biochar and Its Utilization for Metal/Metalloid Immobilization in Contaminated Soil. Sci. Total Environ. 2018, 640-641, 704-713. [CrossRef]

41. Rao, Z.; Niu, S.; Zhan, N.; Wang, X.; Song, X. Microplastics in Sediments of River Yongfeng from Maanshan City, Anhui Province, China. Bull. Environ. Contam. Toxicol. 2020, 104, 166-172. [CrossRef]

42. Torkzaban, S.; Bradford, S.A.; van Genuchten, M.T.; Walker, S.L. Colloid Transport in Unsaturated Porous Media: The Role of Water Content and Ionic Strength on Particle Straining. J. Contam. Hydrol. 2008, 96, 113-127. [CrossRef]

43. Ma, Y.; Wang, L.; Wang, T.; Chen, Q.; Ji, R. Microplastics as Vectors of Chemicals and Microorganisms in the Environment. In Particulate Plastics in Terrestrial and Aquatic Environments; CRC Press: Boca Raton, FL, USA, 2020; pp. 209-230. [CrossRef]

44. Wang, F.; Zhang, X.; Zhang, S.; Zhang, S.; Adams, C.A.; Sun, Y. Effects of Co-Contamination of Microplastics and Cd on Plant Growth and Cd Accumulation. Toxics 2020, 8, 36. [CrossRef] [PubMed]

45. Garçon, M.; Sauzéat, L.; Carlson, R.W.; Shirey, S.B.; Simon, M.; Balter, V.; Boyet, M. Nitrile, Latex, Neoprene and Vinyl Gloves: A Primary Source of Contamination for Trace Element and Zn Isotopic Analyses in Geological and Biological Samples. Geostand. Geoanalytical Res. 2017, 41, 367-380. [CrossRef]

46. Turner, A.; Holmes, L.; Thompson, R.C.; Fisher, A.S. Metals and Marine Microplastics: Adsorption from the Environment versus Addition during Manufacture, Exemplified with Lead. Water Res. 2020, 173, 115577. [CrossRef]

47. Fred-Ahmadu, O.H.; Bhagwat, G.; Oluyoye, I.; Benson, N.U.; Ayejuyo, O.O.; Palanisami, T. Interaction of Chemical Contaminants with Microplastics: Principles and Perspectives. Sci. Total Environ. 2020, 706, 135978. [CrossRef]

48. Do Carmo Ramos, S.N.; Xavier, A.L.P.; Teodoro, F.S.; Gil, L.F.; Gurgel, L.V.A. Removal of Cobalt(II), Copper(II), and Nickel(II) Ions from Aqueous Solutions Using Phthalate-Functionalized Sugarcane Bagasse: Mono- and Multicomponent Adsorption in Batch Mode. Ind. Crops Prod. 2016, 79, 116-130. [CrossRef]

49. Isobe, A.; Kubo, K.; Tamura, Y.; Kako, S.; Nakashima, E.; Fujii, N. Selective Transport of Microplastics and Mesoplastics by Drifting in Coastal Waters. Mar. Pollut. Bull. 2014, 89, 324-330. [CrossRef]

50. De Souza Machado, A.A.; Lau, C.W.; Kloas, W.; Bergmann, J.; Bachelier, J.B.; Faltin, E.; Becker, R.; Görlich, A.S.; Rillig, M.C. Microplastics Can Change Soil Properties and Affect Plant Performance. Environ. Sci. Technol. 2019, 53, 6044-6052. [CrossRef] [PubMed]

51. Horton, A.A.; Dixon, S.J. Microplastics: An Introduction to Environmental Transport Processes. Wiley Interdiscip. Rev. Water 2018, 5, e1268. [CrossRef]

52. Zhang, S.; Han, B.; Sun, Y.; Wang, F. Microplastics Influence the Adsorption and Desorption Characteristics of Cd in an Agricultural Soil. J. Hazard. Mater. 2020, 388, 121775. [CrossRef]

53. Whitacre, D.M. Reviews of Environmental Contamination and Toxicology; Springer: New York, NY, USA, 2014; Volume 229. [CrossRef]

54. Jahnke, A.; Arp, H.P.H.; Escher, B.I.; Gewert, B.; Gorokhova, E.; Kühnel, D.; Ogonowski, M.; Potthoff, A.; Rummel, C.; Schmitt-Jansen, M.; et al. Reducing Uncertainty and Confronting Ignorance about the Possible Impacts of Weathering Plastic in the Marine Environment. Environ. Sci. Technol. Lett. 2017, 4, 85-90. [CrossRef]

55. Liu, P.; Zhan, X.; Wu, X.; Li, J.; Wang, H.; Gao, S. Effect of Weathering on Environmental Behavior of Microplastics: Properties, Sorption and Potential Risks. Chemosphere 2020, 242, 125193. [CrossRef] 
56. Alimi, O.S.; Farner Budarz, J.; Hernandez, L.M.; Tufenkji, N. Microplastics and Nanoplastics in Aquatic Environments: Aggregation, Deposition, and Enhanced Contaminant Transport. Environ. Sci. Technol. 2018, 52, 1704-1724. [CrossRef]

57. Dong, M.; Zhang, Q.; Xing, X.; Chen, W.; She, Z.; Luo, Z. Raman Spectra and Surface Changes of Microplastics Weathered under Natural Environments. Sci. Total Environ. 2020, 739, 139990. [CrossRef]

58. Palmisano, A.C.; Pettigrew, C.A. Biodegradability of Plastics. Bioscience 1992, 42, 680-685. [CrossRef]

59. Orhan, Y.; Hrenović, J.; Büyükgüngör, H. Biodegradation of plastic compost bags under controlled soil conditions. Acta Chim. Slov. 2004, 51, 579-588.

60. Ren, Z.; Gui, X.; Xu, X.; Zhao, L.; Qiu, H.; Cao, X. Microplastics in the Soil-Groundwater Environment: Aging, Migration, and Co-Transport of Contaminants-A Critical Review. J. Hazard. Mater. 2021, 419, 126455. [CrossRef]

61. Binda, G.; Spanu, D.; Monticelli, D.; Pozzi, A.; Bellasi, A.; Bettinetti, R.; Carnati, S.; Nizzetto, L. Unfolding the Interaction between Microplastics and (Trace) Elements in Water: A Critical Review. Water Res. 2021, 204, 117637. [CrossRef]

62. Wijesekara, H.; Bolan, N.S.; Bradney, L.; Obadamudalige, N.; Seshadri, B.; Kunhikrishnan, A.; Dharmarajan, R.; Ok, Y.S.; Rinklebe, J.; Kirkham, M.B.; et al. Trace Element Dynamics of Biosolids-Derived Microbeads. Chemosphere 2018, 199, 331-339. [CrossRef]

63. Li, X.; Mei, Q.; Chen, L.; Zhang, H.; Dong, B.; Dai, X.; He, C.; Zhou, J. Enhancement in Adsorption Potential of Microplastics in Sewage Sludge for Metal Pollutants after the Wastewater Treatment Process. Water Res. 2019, 157, 228-237. [CrossRef]

64. Joshi, P.M.; Juwarkar, A.A. In Vivo Studies to Elucidate the Role of Extracellular Polymeric Substances from Azotobacter in Immobilization of Heavy Metals. Environ. Sci. Technol. 2009, 43, 5884-5889. [CrossRef] [PubMed]

65. Murphy, F.; Ewins, C.; Carbonnier, F.; Quinn, B. Wastewater Treatment Works (WwTW) as a Source of Microplastics in the Aquatic Environment. Environ. Sci. Technol. 2016, 50, 5800-5808. [CrossRef] [PubMed]

66. Cui, N.; Qu, L.; Wu, G. Heavy Metal Accumulation Characteristics and Physiological Response of Sabina Chinensis and Platycladus Orientalis to Atmospheric Pollution. J. Environ. Sci. 2022, 112, 192-201. [CrossRef] [PubMed]

67. Zhang, J.; Li, X.; Guo, L.; Deng, Z.; Wang, D.; Liu, L. Assessment of Heavy Metal Pollution and Water Quality Characteristics of the Reservoir Control Reaches in the Middle Han River, China. Sci. Total Environ. 2021, 799, 149472. [CrossRef] [PubMed]

68. El Alouani, M.; Saufi, H.; Moutaoukil, G.; Alehyen, S.; Nematollahi, B.; Belmaghraoui, W.; Taibi, M. Application of Geopolymers for Treatment of Water Contaminated with Organic and Inorganic Pollutants: State-of-the-Art Review. J. Environ. Chem. Eng. 2021, 9, 105095. [CrossRef]

69. Gadore, V.; Ahmaruzzaman, M. Tailored Fly Ash Materials: A Recent Progress of Their Properties and Applications for Remediation of Organic and Inorganic Contaminants from Water. J. Water Process Eng. 2021, 41, 101910. [CrossRef]

70. Taherlou, A.; Asadollahfardi, G.; Salehi, A.M.; Katebi, A. Sustainable Use of Municipal Solid Waste Incinerator Bottom Ash and the Treated Industrial Wastewater in Self-Compacting Concrete. Constr. Build. Mater. 2021, 297, 123814. [CrossRef]

71. Szopińska, M.; Luczkiewicz, A.; Jankowska, K.; Fudala-Ksiazek, S.; Potapowicz, J.; Kalinowska, A.; Bialik, R.J.; Chmiel, S.; Polkowska, Ż. First Evaluation of Wastewater Discharge Influence on Marine Water Contamination in the Vicinity of Arctowski Station (Maritime Antarctica). Sci. Total Environ. 2021, 789, 147912. [CrossRef]

72. Danouche, M.; El Ghachtouli, N.; El Arroussi, H. Phycoremediation Mechanisms of Heavy Metals Using Living Green Microalgae: Physicochemical and Molecular Approaches for Enhancing Selectivity and Removal Capacity. Heliyon 2021, 5, e02477. [CrossRef]

73. Rahaman, M.H.; Islam, M.A.; Islam, M.M.; Rahman, M.A.; Alam, S.M.N. Biodegradable Composite Adsorbent of Modified Cellulose and Chitosan to Remove Heavy Metal Ions from Aqueous Solution. Curr. Res. Green Sustain. Chem. 2021, 4 , 100119. [CrossRef]

74. Demey, H.; Vincent, T.; Guibal, E. A Novel Algal-Based Sorbent for Heavy Metal Removal. Chem. Eng. J. 2018, $332,582-595$. [CrossRef]

75. Feng, Z.; Ji, S.; Ping, J.; Cui, D. Recent Advances in Metabolomics for Studying Heavy Metal Stress in Plants. TrAC-Trends Anal. Chem. 2021, 143, 116402. [CrossRef]

76. Yang, D.; Liu, Y.; Liu, S.; Li, C.; Zhao, Y.; Li, L.; Lu, S. Exposure to Heavy Metals and Its Association with DNA Oxidative Damage in Municipal Waste Incinerator Workers in Shenzhen, China. Chemosphere 2020, 250, 126289. [CrossRef]

77. Naikoo, M.I.; Khan, F.A.; Noureldeen, A.; Rinklebe, J.; Sonne, C.; Rajakaruna, N.; Ahmad, P. Biotransfer, Bioaccumulation and Detoxification of Nickel along the Soil-Faba Bean-Aphid-Ladybird Food Chain. Sci. Total Environ. 2021, 785, 147226. [CrossRef]

78. Vieira, K.S.; Baptista Neto, J.A.; Crapez, M.A.C.; Gaylarde, C.; da Silva Pierri, B.; Saldaña-Serrano, M.; Bainy, A.C.D.; Nogueira, D.J.; Fonseca, E.M. Occurrence of Microplastics and Heavy Metals Accumulation in Native Oysters Crassostrea Gasar in the Paranaguá Estuarine System, Brazil. Mar. Pollut. Bull. 2021, 166, 112225. [CrossRef]

79. Xiang, Y.; Jiang, L.; Zhou, Y.; Luo, Z.; Zhi, D.; Yang, J.; Lam, S.S. Microplastics and Environmental Pollutants: Key Interaction and Toxicology in Aquatic and Soil Environments. J. Hazard. Mater. 2022, 422, 126843. [CrossRef]

80. Capriotti, M.; Cocci, P.; Bracchetti, L.; Cottone, E.; Scandiffio, R.; Caprioli, G.; Sagratini, G.; Mosconi, G.; Bovolin, P.; Palermo, F.A. Microplastics and Their Associated Organic Pollutants from the Coastal Waters of the Central Adriatic Sea (Italy): Investigation of Adipogenic Effects in Vitro. Chemosphere 2021, 263, 128090. [CrossRef]

81. Fu, L.; Li, J.; Wang, G.; Luan, Y.; Dai, W. Adsorption Behavior of Organic Pollutants on Microplastics. Ecotoxicol. Environ. Saf. 2021, 217, 112207. [CrossRef]

82. Ricardo, I.A.; Alberto, E.A.; Silva Júnior, A.H.; Macuvele, D.L.P.; Padoin, N.; Soares, C.; Gracher Riella, H.; Starling, M.C.V.M.; Trovó, A.G. A Critical Review on Microplastics, Interaction with Organic and Inorganic Pollutants, Impacts and Effectiveness of Advanced Oxidation Processes Applied for Their Removal from Aqueous Matrices. Chem. Eng. J. 2021, 424, 130282. [CrossRef] 
83. Hahladakis, J.N.; Velis, C.A.; Weber, R.; Iacovidou, E.; Purnell, P. An Overview of Chemical Additives Present in Plastics: Migration, Release, Fate and Environmental Impact during Their Use, Disposal and Recycling. J. Hazard. Mater. 2018, 344, 179-199. [CrossRef]

84. Vaid, M.; Sarma, K.; Gupta, A. Microplastic Pollution in Aquatic Environments with Special Emphasis on Riverine Systems: Current Understanding and Way Forward. J. Environ. Manag. 2021, 293, 112860. [CrossRef] [PubMed]

85. Liu, Y.; Guo, R.; Zhang, S.; Sun, Y.; Wang, F. Uptake and Translocation of Nano/Microplastics by Rice Seedlings: Evidence from a Hydroponic Experiment. J. Hazard. Mater. 2022, 421, 126700. [CrossRef] [PubMed]

86. Watteau, F.; Dignac, M.F.; Bouchard, A.; Revallier, A.; Houot, S. Microplastic Detection in Soil Amended With Municipal Solid Waste Composts as Revealed by Transmission Electronic Microscopy and Pyrolysis/GC/MS. Front. Sustain. Food Syst. 2018, 2, 1-14. [CrossRef]

87. O'Connor, D.; Pan, S.; Shen, Z.; Song, Y.; Jin, Y.; Wu, W.M.; Hou, D. Microplastics Undergo Accelerated Vertical Migration in Sand Soil Due to Small Size and Wet-Dry Cycles. Environ. Pollut. 2019, 249, 527-534. [CrossRef]

88. Bosker, T.; Bouwman, L.J.; Brun, N.R.; Behrens, P.; Vijver, M.G. Microplastics Accumulate on Pores in Seed Capsule and Delay Germination and Root Growth of the Terrestrial Vascular Plant Lepidium Sativum. Chemosphere 2019, 226, 774-781. [CrossRef]

89. Jiang, X.; Chen, H.; Liao, Y.; Ye, Z.; Li, M.; Klobučar, G. Ecotoxicity and Genotoxicity of Polystyrene Microplastics on Higher Plant Vicia Faba. Environ. Pollut. 2019, 250, 831-838. [CrossRef]

90. Dong, Y.; Gao, M.; Qiu, W.; Song, Z. Effect of Microplastics and Arsenic on Nutrients and Microorganisms in Rice Rhizosphere Soil. Ecotoxicol. Environ. Saf. 2021, 211, 111899. [CrossRef]

91. Meng, F.; Yang, X.; Riksen, M.; Xu, M.; Geissen, V. Response of Common Bean (Phaseolus vulgaris L.) Growth to Soil Contaminated with Microplastics. Sci. Total Environ. 2021, 755, 142516. [CrossRef]

92. Kim, S.W.; Kim, D.; Chae, Y.; Kim, D.; An, Y.J. Crop-Dependent Changes in Water Absorption of Expanded Polystyrene in Soil Environments. Chemosphere 2019, 219, 345-350. [CrossRef]

93. Wang, F.; Wang, X.; Song, N. Polyethylene Microplastics Increase Cadmium Uptake in Lettuce (Lactuca sativa L.) by Altering the Soil Microenvironment. Sci. Total Environ. 2021, 784, 147133. [CrossRef]

94. Giorgetti, L.; Spanò, C.; Muccifora, S.; Bottega, S.; Barbieri, F.; Bellani, L.; Ruffini Castiglione, M. Exploring the Interaction between Polystyrene Nanoplastics and Allium Cepa during Germination: Internalization in Root Cells, Induction of Toxicity and Oxidative Stress. Plant Physiol. Biochem. 2020, 149, 170-177. [CrossRef]

95. Li, L.; Luo, Y.; Li, R.; Zhou, Q.; Peijnenburg, W.J.G.M.; Yin, N.; Yang, J.; Tu, C.; Zhang, Y. Effective Uptake of Submicrometre Plastics by Crop Plants via a Crack-Entry Mode. Nat. Sustain. 2020, 3, 929-937. [CrossRef]

96. Lian, J.; Wu, J.; Xiong, H.; Zeb, A.; Yang, T.; Su, X.; Su, L.; Liu, W. Impact of Polystyrene Nanoplastics (PSNPs) on Seed Germination and Seedling Growth of Wheat (Triticum aestivum L.). J. Hazard. Mater. 2020, 385, 121620. [CrossRef]

97. Liu, Z.; Wei, H.; Zhang, J.; Saleem, M.; He, Y.; Zhong, J.; Ma, R. Seasonality Regulates the Effects of Acid Rain on Microbial Community in a Subtropical Agricultural Soil of Southern China. Ecotoxicol. Environ. Saf. 2021, 224, 112681. [CrossRef]

98. Wu, X.; Liu, Y.; Yin, S.; Xiao, K.; Xiong, Q.; Bian, S.; Liang, S.; Hou, H.; Hu, J.; Yang, J. Metabolomics Revealing the Response of Rice (Oryza sativa L.) Exposed to Polystyrene Microplastics. Environ. Pollut. 2020, 266, 115159. [CrossRef]

99. Dong, Y.; Gao, M.; Song, Z.; Qiu, W. Microplastic Particles Increase Arsenic Toxicity to Rice Seedlings. Environ. Pollut. 2020, 259, 113892. [CrossRef]

100. Li, L.; Zhou, Q.; Yin, N.; Tu, C.; Luo, Y. Uptake and Accumulation of Microplastics in an Edible Plant. Kexue Tongbao/Chin. Sci. Bull. 2019, 64, 928-934. [CrossRef]

101. Zequan, Z.; Changsheng, S.H.U.; Xuefang, D.; Yunping, L.; Jun, L.; Huiting, W.; Zhengsong, P.; Wuyun, Y. Effect of Low Temperature on Seed Germination and Seedling Growth in Wheat. Southwest China J. Agric. Sci. 2010, $23,22-25$.

102. Qi, Y.; Yang, X.; Pelaez, A.M.; Huerta Lwanga, E.; Beriot, N.; Gertsen, H.; Garbeva, P.; Geissen, V. Macro- and Micro- Plastics in Soil-Plant System: Effects of Plastic Mulch Film Residues on Wheat (Triticum aestivum) Growth. Sci. Total Environ. 2018, 645, 1048-1056. [CrossRef]

103. Lozano, Y.M.; Lehnert, T.; Linck, L.T.; Lehmann, A.; Rillig, M.C. Microplastic Shape, Polymer Type, and Concentration Affect Soil Properties and Plant Biomass. Front. Plant Sci. 2021, 12, 1-14. [CrossRef]

104. Liu, S.; Wang, J.; Zhu, J.; Wang, J.; Wang, H.; Zhan, X. The Joint Toxicity of Polyethylene Microplastic and Phenanthrene to Wheat Seedlings. Chemosphere 2021, 282, 130967. [CrossRef]

105. Urbina, M.A.; Correa, F.; Aburto, F.; Ferrio, J.P. Adsorption of Polyethylene Microbeads and Physiological Effects on Hydroponic Maize. Sci. Total Environ. 2020, 741, 140216. [CrossRef]

106. Pignattelli, S.; Broccoli, A.; Renzi, M. Physiological Responses of Garden Cress (L. sativum) to Different Types of Microplastics. Sci. Total Environ. 2020, 727, 138609. [CrossRef]

107. Lozano, Y.M.; Rillig, M.C. Effects of Microplastic Fibers and Drought on Plant Communities. Environ. Sci. Technol. 2020, 54, 6166-6173. [CrossRef]

108. Rychter, P.; Rogacz, D.; Lewicka, K.; Kollár, J.; Kawalec, M.; Mosnáiek, J. Ecotoxicological Properties of Tulipalin A-Based Superabsorbents versus Conventional Superabsorbent Hydrogels. Adv. Polym. Technol. 2019, 2019, 2947152. [CrossRef]

109. Rong, L.; Zhao, L.; Zhao, L.; Cheng, Z.; Yao, Y.; Yuan, C.; Wang, L.; Sun, H. LDPE Microplastics Affect Soil Microbial Communities and Nitrogen Cycling. Sci. Total Environ. 2021, 773, 145640. [CrossRef] 
110. Zhou, J.; Gui, H.; Banfield, C.C.; Wen, Y.; Zang, H.; Dippold, M.A.; Charlton, A.; Jones, D.L. The Microplastisphere: Biodegradable Microplastics Addition Alters Soil Microbial Community Structure and Function. Soil Biol. Biochem. 2021, 156, 108211. [CrossRef]

111. Qi, R.; Jones, D.L.; Li, Z.; Liu, Q.; Yan, C. Behavior of Microplastics and Plastic Film Residues in the Soil Environment: A Critical Review. Sci. Total Environ. 2020, 703, 134722. [CrossRef]

112. Fu, Q.; Lai, J.L.; Ji, X.H.; Luo, Z.X.; Wu, G.; Luo, X.G. Alterations of the Rhizosphere Soil Microbial Community Composition and Metabolite Profiles of Zea Mays by Polyethylene-Particles of Different Molecular Weights. J. Hazard. Mater. 2022, $423,127062$. [CrossRef] [PubMed]

113. Huang, D.; Xu, Y.; Lei, F.; Yu, X.; Ouyang, Z.; Chen, Y.; Jia, H.; Guo, X. Degradation of Polyethylene Plastic in Soil and Effects on Microbial Community Composition. J. Hazard. Mater. 2021, 416, 126173. [CrossRef] [PubMed]

114. Xu, M.; Du, W.; Ai, F.; Xu, F.; Zhu, J.; Yin, Y.; Ji, R.; Guo, H. Polystyrene Microplastics Alleviate the Effects of Sulfamethazine on Soil Microbial Communities at Different CO2 Concentrations. J. Hazard. Mater. 2021, 413, 125286. [CrossRef] [PubMed]

115. Wang, L.; Li, X.G.; Lv, J.; Fu, T.; Ma, Q.; Song, W.; Wang, Y.P.; Li, F.M. Continuous Plastic-Film Mulching Increases Soil Aggregation but Decreases Soil PH in Semiarid Areas of China. Soil Tillage Res. 2017, 167, 46-53. [CrossRef]

116. Liu, H.; Yang, X.; Liu, G.; Liang, C.; Xue, S.; Chen, H.; Ritsema, C.J.; Geissen, V. Response of Soil Dissolved Organic Matter to Microplastic Addition in Chinese Loess Soil. Chemosphere 2017, 185, 907-917. [CrossRef]

117. Chen, H.; Wang, Y.; Sun, X.; Peng, Y.; Xiao, L. Mixing Effect of Polylactic Acid Microplastic and Straw Residue on Soil Property and Ecological Function. Chemosphere 2020, 243, 125271. [CrossRef]

118. Fei, Y.; Huang, S.; Zhang, H.; Tong, Y.; Wen, D.; Xia, X.; Wang, H.; Luo, Y.; Barceló, D. Response of Soil Enzyme Activities and Bacterial Communities to the Accumulation of Microplastics in an Acid Cropped Soil. Sci. Total Environ. 2020, 707, 135634. [CrossRef]

119. Huang, Y.; Zhao, Y.; Wang, J.; Zhang, M.; Jia, W.; Qin, X. LDPE Microplastic Films Alter Microbial Community Composition and Enzymatic Activities in Soil. Environ. Pollut. 2019, 254, 112983. [CrossRef]

120. Seeley, M.E.; Song, B.; Passie, R.; Hale, R.C. Microplastics Affect Sedimentary Microbial Communities and Nitrogen Cycling. Nat. Commun. 2020, 11, 2372. [CrossRef]

121. Pironti, C.; Ricciardi, M.; Motta, O.; Miele, Y.; Proto, A.; Montano, L. Microplastics in the Environment: Intake through the Food Web, Human Exposure and Toxicological Effects. Toxics 2021, 9, 224. [CrossRef]

122. Ricciardi, M.; Pironti, C.; Motta, O.; Miele, Y.; Proto, A.; Montano, L. Microplastics in the Aquatic Environment: Occurrence, Persistence, Analysis, and Human Exposure. Water 2021, 13, 973. [CrossRef]

123. Chae, Y.; An, Y.J. Nanoplastic Ingestion Induces Behavioral Disorders in Terrestrial Snails: Trophic Transfer Effects: Via Vascular Plants. Environ. Sci. Nano 2020, 7, 975-983. [CrossRef]

124. Rainieri, S.; Conlledo, N.; Larsen, B.K.; Granby, K.; Barranco, A. Combined Effects of Microplastics and Chemical Contaminants on the Organ Toxicity of Zebrafish (Danio rerio). Environ. Res. 2018, 162, 135-143. [CrossRef] [PubMed]

125. Sun, X.D.; Yuan, X.Z.; Jia, Y.; Feng, L.J.; Zhu, F.P.; Dong, S.S.; Liu, J.; Kong, X.; Tian, H.; Duan, J.L.; et al. Differentially Charged Nanoplastics Demonstrate Distinct Accumulation in Arabidopsis Thaliana. Nat. Nanotechnol. 2020, 15, 755-760. [CrossRef] [PubMed]

126. Gao, M.; Liu, Y.; Song, Z. Effects of Polyethylene Microplastic on the Phytotoxicity of Di-n-Butyl Phthalate in Lettuce (Lactuca sativa L. var. ramosa Hort). Chemosphere 2019, 237, 124482. [CrossRef] [PubMed]

127. Hu, Q.; Li, X.; Gonçalves, J.M.; Shi, H.; Tian, T.; Chen, N. Effects of Residual Plastic-Film Mulch on Field Corn Growth and Productivity. Sci. Total Environ. 2020, 729, 138901. [CrossRef]

128. Rillig, M.C.; Ingraffia, R.; De Souza Machado, A.A. Microplastic Incorporation into Soil in Agroecosystems. Front. Plant Sci. 2017, 8, 1805. [CrossRef]

129. Rochman, C.M.; Cook, A.-M.; Koelmans, A.A. Plastic Debris and Policy: Using Current Scientific Understanding to Invoke Positive Change. Environ. Toxicol. Chem. 2016, 35, 1617-1626. [CrossRef]

130. Harris, L.S.T.; Fennell, J.; Fales, R.J.; Carrington, E. Spatial-Temporal Growth, Distribution, and Diffusion of Marine Microplastic Research and National Plastic Policies. Water Air Soil Pollut. 2021, 232, 400. [CrossRef]

131. Guerranti, C.; Martellini, T.; Perra, G.; Scopetani, C.; Cincinelli, A. Microplastics in Cosmetics: Environmental Issues and Needs for Global Bans. Environ. Toxicol. Pharmacol. 2019, 68, 75-79. [CrossRef]

132. Xanthos, D.; Walker, T.R. International Policies to Reduce Plastic Marine Pollution from Single-Use Plastics (Plastic Bags and Microbeads): A Review. Mar. Pollut. Bull. 2017, 118, 17-26. [CrossRef]

133. Galarpe, V.R.K.R.; Jaraula, C.M.B.; Paler, M.K.O. The Nexus of Macroplastic and Microplastic Research and Plastic Regulation Policies in the Philippines Marine Coastal Environments. Mar. Pollut. Bull. 2021, 167, 112343. [CrossRef]

134. Liang, Y.; Tan, Q.; Song, Q.; Li, J. An Analysis of the Plastic Waste Trade and Management in Asia. Waste Manag. 2021, 119, 242-253. [CrossRef]

135. Rochman, C.M.; Polhemus, D.; Wyer, H.; Coffin, S.; Moore, S.; Weisberg, S.B. Steps Scientists Can Take to Inform Aquatic Microplastics Management: A Perspective Informed by the California Experience. Appl. Spectrosc. 2020, 74, 971-975.

136. Milojevic, N.; Cydzik-Kwiatkowska, A. Agricultural Use of Sewage Sludge as a Threat of Microplastic (MP) Spread in the Environment and the Role of Governance. Energies 2021, 14, 6293. [CrossRef]

137. Christodoulou, A.; Stamatelatou, K. Overview of Legislation on Sewage Sludge Management in Developed Countries Worldwide. Water Sci. Technol. 2016, 73, 453-462. [CrossRef] 
138. Deme, G.G.; Ewusi-Mensah, D.; Olagbaju, O.A.; Okeke, E.S.; Okoye, C.O.; Odii, E.C.; Ejeromedoghene, O.; Igun, E.; Onyekwere, J.O.; Oderinde, O.K.; et al. Macro Problems from Microplastics: Toward a Sustainable Policy Framework for Managing Microplastic Waste in Africa. Sci. Total Environ. 2022, 804, 150170. [CrossRef]

139. Gil-Ortiz, R.; Naranjo, M.Á.; Ruiz-Navarro, A.; Atares, S.; García, C.; Zotarelli, L.; Bautista, A.S.; Vicente, O. Enhanced Agronomic Efficiency Using a New Controlled-Released, Polymeric-Coated Nitrogen Fertilizer in Rice. Plants 2020, 9, 1183. [CrossRef]

140. Deng, L.; Cai, L.; Sun, F.; Li, G.; Che, Y. Public Attitudes towards Microplastics: Perceptions, Behaviors and Policy Implications. Resour. Conserv. Recycl. 2020, 163, 105096. [CrossRef]

141. Barcelo, D.; Pico, Y. Case Studies of Macro- and Microplastics Pollution in Coastal Waters and Rivers: Is There a Solution with New Removal Technologies and Policy Actions? Case Stud. Chem. Environ. Eng. 2020, 2, 100019. [CrossRef] 